Original research article

\title{
Comparing the Confusion Assessment Method for the Intensive Care Unit and Neelon and Champagne Confusion Scale for assessing delirium in non-intubated intensive care patients
}

\author{
Hana Locihová ${ }^{1,2,3 *(i D)}$, Jana Pelikánová ${ }^{4}$ \\ ${ }^{1}$ University of Ostrava, Faculty of Medicine, Department of Intensive Medicine, Emergency Medicine and Forensic Studies, Ostrava, Czech Republic \\ ${ }^{2}$ AGEL Educational and Research Institute (VIA), Prostějov, Czech Republic \\ ${ }^{3}$ AGEL Secondary Nursing School and Higher Nursing School, Ostrava, Czech Republic \\ ${ }^{4}$ AGEL Hospital Valašské Meziřičí, Valašské Meziřičcí, Czech Republic
}

\begin{abstract}
Introduction: There are many scales of assessment and prediction of risk of delirium, but they are little known and rarely used by professionals. Recognition of delirium by nurses continues to be limited.

Design: The prospective observational study included 50 consecutive non-intubated patients staying in the ICU for more than 24 hours. Setting: Department of anesthesiology and intensive care medicine ( 5 beds) of AGEL Hospital in Valašské Meziřičí, between September 2020 and March 2021.

Methods: Primary outcome was to compare the presence of delirium in non-intubated ICU patients with two simultaneously used assessment tools: the Neelon and Champagne (NEECHAM) Confusion Scale, and the Confusion Assessment Method for the Intensive Care Unit (CAM-ICU). A secondary outcome was to verify the NEECHAM Confusion Scale reliability in the Czech ICU setting.

Results: The study found that the incidence rates detected by the CAM-ICU (32\%) and NEECHAM Confusion Scale (28\%) were comparable. Nearly a third of CAM-ICU-negative patients were found to belong to the mild confusion or at-risk NEECHAM Confusion Scale groups. The internal consistency of the NEECHAM Confusion Scale assessed with Cronbach's a was 0.703. There was a statistically significant relationship between delirium and two of the studied patient parameters (GCS score and use of antipsychotics).

Conclusions: Delirium is common in ICU patients, but it often remains undiagnosed. Various tools have been developed to help identify delirium patients. Their use has been shown to result in better outcomes. Both studied tools (the CAM-ICU and NEECHAM Confusion Scale) appear to be suitable and convenient.
\end{abstract}

Keywords: Acute nursing; CAM-ICU; Delirium; Intensive Care Unit; NEECHAM Confusion Scale; Non-intubated patients

\section{Introduction}

There is sufficient evidence to suggest that delirium is a negative prognostic factor associated with unfavorable indicators of hospitalization (Zhang et al., 2013). The incidence of delirium in the Intensive Care Unit (ICU) ranges widely, from $16 \%$ to $89 \%$. This variability is due to numerous methodological differences between available studies, including the assessment tool used, the patient population studied (e.g. age, disease severity, mechanical ventilation) and the staff's training level (Devlin et al., 2018). Based on its clinical manifestations, delirium may be classified as hyperactive, hypoactive or mixed. According to some studies (Serafim et al., 2017), hyperac- tive delirium accounts for less than $2 \%$ of cases and is more common in younger patients. It is characterized by agitation, verbal and physical aggression, hallucinations and delusions, psychomotor restlessness, and endangering oneself and others. This type of delirium is easy to recognize and is usually rapidly managed using medications with varied effectiveness. The hypoactive type is observed in more than $40 \%$ of delirium patients, particularly those in older age groups (Serafim et al., 2017). It manifests in apathy, lethargy, sleepiness and passivity. Hypoactive delirium is associated with higher mortality. It is difficult to diagnose and often untreated. In the most frequent mixed type, the phases alternate with varied intensity and duration (Cherak et al., 2020). Nurses are most familiar with the hyperactive form, they often tend to overlook hypo-

\footnotetext{
* Corresponding author: Hana Locihová, University of Ostrava, Faculty of Medicine, Department of Intensive Medicine, Emergency Medicine and Forensic Studies, Ostrava, Czech Republic; e-mail: H.Reichelova@seznam.cz (H. Locihová)

http://doi.org/10.32725/kont.2022.006

Submitted: 2021-07-18 • Accepted: 2022-01-24 • Prepublished online: 2022-03-03

KONTAKT 24/1: 36-42 • EISSN 1804-7122 • ISSN 1212-4117

(c) 2022 The Authors. Published by University of South Bohemia in České Budějovice, Faculty of Health and Social Sciences.

This is an open access article under the CC BY-NC-ND license.
} 
active delirium in patients (Helgesen et al., 2021). Research has shown that over $60 \%$ of all delirium patients are missed by physicians and nurses (Pun and Ely, 2007).

The risk factors for the development of delirium are either predisposing (non-modifiable), such as age over 65 years, underlying disease and preexisting cognitive impairment (dementia), or precipitating (partially modifiable), such as transport, social isolation, sleep disturbances and polypharmacy (Ho et al., 2020). In delirium, prevention aimed at the precipitating factors is currently emphasized (Černá Pařízková 2019; Káňová et al., 2015). In the ICU setting, the ability to accurately assess delirium is a key component of any systematic strategy to prevent and/or treat delirium. The diagnosis is made using standardized diagnostic assessment tools, which contributes to the early detection of delirium and the selection of adequate nursing interventions (Balková and Tomagová, 2018). In ICU patients, routine screening is recommended (Devlin et al., 2018, Ho et al., 2020). The Confusion Assessment Method (CAM-ICU ) is a well-validated and frequently used tool (Arabic, Chinese, Danish, Dutch, German, etc.). It is widely accepted as the gold standard in intensive care delirium assessment. A Brazilian review by Gusmao-Flores et al. (2012) showed that CAM-ICU was a good diagnostic instrument in critically ill patients (pooled sensitivity $80.0 \%$, pooled specificity 95.9\%). Because the patient in intensive care is not always able to communicate verbally, the CAM-ICU was adapted to screen intubated or artificially ventilated patients (Cribbin, 2018). The results of this scale are limited by the binomial approach of the evaluation of delirium, and the fact that it is a one-point-in-time assessment (Waterfield, Barnason 2021). The Neelon and Champagne (NEECHAM) Confusion Scale was developed a few years later, based on daily nursing practice: the nurses' 24-hour assessment of the level of processing information, the level of behavior, and the physiological condition rate. The NEECHAM scale is reliable for the detection of delirium by nurses in the general hospital population (Poikajärvi et al., 2017). It has also been validated for use in the intensive care environment (Ashtarian et al., 2019; Van Rompaey et al., 2008). An Italian study by Matarese et al. (2013) states that this NEECHAM scale is applicable with nonventilated intensive care patients. A Finnish study by Poikajärvi et al. (2017) states that internal consistency NEECHAM (Cronbach's $\alpha$ ) was $0.80(0.725,0.862)$. Concurrent validity between the CAM and the NEECHAM showed positive correlation $\left(r_{\mathrm{s}}=0.59\right)$ in groups $(p<0.01)$. Other studies (Grover and Kate, 2012; Immers et al., 2005; Matarese at al., 2013) reported the sensitivity of this instrument as 95, 97, and 99, respectively.

\section{Objective}

The main aim was to compare the presence of delirium in non-intubated ICU patients with two simultaneously used assessment tools: the Neelon and Champagne (NEECHAM) Confusion Scale, and the Confusion Assessment Method for the Intensive Care Unit (CAM-ICU). A secondary objective was to verify the NEECHAM Confusion Scale reliability in the Czech ICU setting.

\section{Materials and methods}

\section{Design}

Prospective observational study.

\section{Patients}

The sample comprised 50 consecutive patients staying in the department of anesthesiology and intensive care medicine (5 beds) of AGEL Hospital in Valašské Meziříčí (for more than 24 hours, between September 2020 and March 2021). Excluded from the study were terminal patients, those under deep sedation (RASS score below -4), those with impaired consciousness (Glasgow Coma Scale [GCS] score below 12) or dementia, COVID-19-positive patients, and individuals refusing to participate in the study (Fig. 1).

\section{Data collection}

To detect delirium, two assessment tools were used concurrently (the NEECHAM Confusion Scale and CAM-ICU). Delirium screening was performed twice daily by nurses in 50 patients throughout their hospital stay (for up to 28 days). First, the patient was assessed with the NEECHAM scale without calculating the results, and then immediately afterwards with the CAM-ICU. A total of 389 paired questionnaires were obtained. On average, the questionnaires took 5-10 minutes to complete.

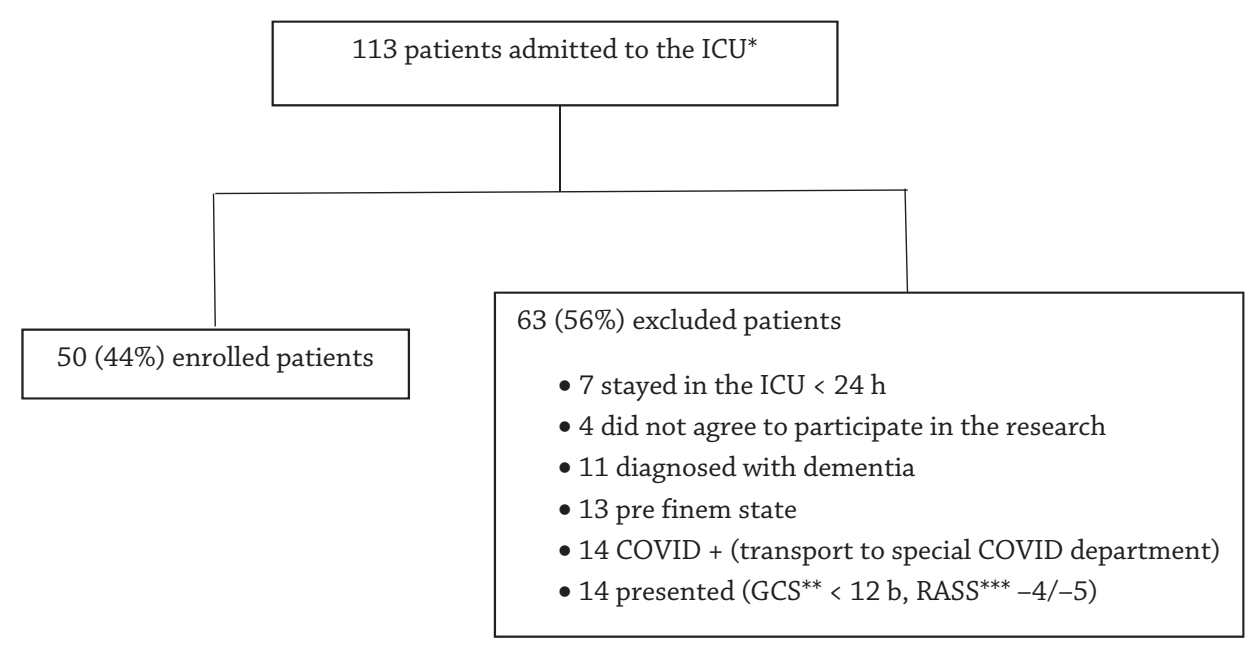

Legend: ${ }^{*}$ ICU: Intensive Care Unit, ${ }^{* *}$ GCS: Glasgow Coma Scale, ${ }^{* * *}$ RASS: Richmond Agitation Sedation Scale.

Fig. 1. Flowchart of patients in the study 


\section{Process of translation}

The CAM-ICU was validated by a team of experts from Brno (Mitášová et al., 2010) who consented to the use of their Czech version in the present study. The original NEECHAM Confusion Scale was requested directly from one of its authors (Prof. Neelon). In accordance with the guidelines and standards for the translation and cultural adaptation of patient-reported outcome measures, the tool was translated and linguistically validated (Wild et al., 2005).

The translation of the questionnaire proceeded in the following steps:

1. Forward translation: translation from the English version into Czech language by independent professional translators. This included the creation of a unified $C z e c h$ version.

2. Backward translation: a backward translation in English, which was compared with the original questionnaire after its completion. Subsequently, the translator commented on the differences between the original and the backward translation and suggested the adaptation of the items in Czech.

3. Expert group: after the translation phase, an expert group consisting of an academic and four nurses met. The purpose of the meeting was to agree that the proposed final translation is equivalent to the original questionnaire and that the Czech items match in terms of the content and semantics.

4. Patient testing: the tool was tested on eight patients (August 2020) at the department of anesthesiology and intensive care of the Hospital in Valašské Meziříčí (not included in the final sample).

5. The process of linguistic validation took 4 weeks.

\section{Assessment instruments: the NEECHAM Confusion Scale vs. CAM-ICU}

In the study, two delirium assessment tools were used. The NEECHAM Confusion Scale total score range runs from 0 (minimal responsiveness) to 30 (normal function). The tool comprises nine scaled items divided into three domains: Cognitive Processing (0-14), Behavior (0-10) and Physiological Control (0-10). The total scores are classified into four categories as follows: $27-30$ = absence of confusion, or normal processing; 25-26 = absence of, but at risk for confusion; 20-24 = mild or early development of confused state; $19-0=$ moderate to severe confusion (Neelon et al., 1996).

When using the CAM-ICU to diagnose delirium, the first step is to assess arousal with the RASS, which is a simple 10-point scale. In deeply sedated patients not responding to any stimulation (RASS score $-4 /-5$ ), the presence of delirium cannot be established. The second step is assessment of four main features of delirium: acute change or fluctuating course of mental status (feature 1), inattention (feature 2), altered level of consciousness (feature 3 ), and disorganized thinking (feature 4). Delirium is deemed positive when feature 1 and 2 (and either feature 3 or 4 ) are present. Otherwise, the patient is CAM-ICU negative. RASS scores ranging from 0 to -3 are associated with hypoactive delirium. A RASS score of +1 to +4 suggests hyperactive delirium. Mixed delirium is when the patient fluctuates between the two forms (Mitášová et al., 2010).

\section{Ethical aspects}

The study, conducted in accordance with the Declaration of Helsinki, was approved by the ethics committee of AGEL Hospital in Valašské Meziřičí. Respondents' participation was voluntary and anonymous. Approval to use the Czech version of the CAM-ICU was obtained from Dr. Mitášová. The
NEECHAM Confusion Scale was translated with the permission of Virginia J. Neelon.

\section{Data analysis}

Relationships between pairs of metric or ordinal variables were tested by a robust Mann-Whitney test at the significance level $p<0.05$. The relationships between dichotomous variables were evaluated using Fisher's exact test. The statistical software, Statgraphics Centurion - version 18.1.06 from Statgraphics Technologies, Inc. (The Plains, Virginia, USA) was used for evaluation. The estimation of the internal consistency was completed using Cronbach's a statistic, following Pearson's correlations. Cronbach's a statistic was calculated using the statistical software NCSS 12 from Number Cruncher Statistical Systems, LLC (Kaysville, Utah, USA).

\section{Results}

Initially, a total of 113 patients were enrolled in the study. Of those, 63 (56\%) were excluded in accordance with the criteria (Fig. 1). The sample comprised 23 males (46\%) and 27 females, with a mean age of 71.5 years. During their hospital stay, 16 participants (32\%) received mechanical ventilation. The median length of ICU and hospital stay was two and 10 days, respectively. Twenty-three patients (46\%) underwent surgery and 40 participants (80\%) required emergency admission. In 11 patients (22\%), physical restraint had to be administered. Of the 50 participants, 13 patients (26\%) died during their hospitalization, including five deaths $(10 \%)$ in the ICU. The median Therapeutic Intervention Scoring System (TISS) score measuring nursing workload was 555 (553, 557), suggesting that mainly conscious, not critically ill, patients were included in the sample. The most frequently administered drugs were opioids (46\%), antipsychotics (38\%), and benzodiazepines (14\%) - Table 1.

The incidence of delirium assessed with the CAM-ICU was $32 \%$ (16 patients); the remaining 68\% (34 patients) were classified as negative using the ICU-CAM. More detailed classification of delirium-positive patients $(n=16)$ using the RASS showed hyperactive delirium in 5 patients (10\%), hypoactive delirium in 7 patients (14\%), and mixed form in 4 patients (8\%). With the NEECHAM Confusion Scale, delirium was diagnosed in $28 \%$, mild confusion in $22 \%$, risk of confusion in $22 \%$, and normal processing in $28 \%$ of cases. Nearly a third of CAM-ICU-negative patients were found positive with the NEECHAM Confusion Scale, belonging to the mild confusion or at-risk groups. Only one ICU-CAM-positive patient was diagnosed as delirious with the NEECHAM Confusion Scale (Fig. 2, Table 2). The internal consistency of the Czech version of the NEECHAM Confusion Scale (previously unreported in the Czech Republic) was calculated from 389 completed questionnaires, with Cronbach's a reaching 0.703 . This value may be interpreted as satisfactory because the acceptable minimum is usually reported at $\alpha>0.70$ (Dušek et al., 2011). The lowest value was found for the Physiological Control domain (Table 3). Detailed analyses of the studied variables with respect to the presence of delirium assessed with the two tools (the NEECHAM Confusion Scale and CAM-ICU) showed that only two variables were statistically significant $(p<0.001)$ : GCS score and use of antipsychotics. The relationships with the other variables were not significant, but hospital stay, ICU stay, Therapeutic Intervention Scoring System (TISS) score, and use of physical restraints were on the borderline of statistical significance (Table 4). 


\begin{tabular}{lc}
$\begin{array}{l}\text { Table 1. Summary statistics at the beginning of the } \\
\text { hospitalization }\end{array}$ & Median (quartiles) \\
\hline$n=50$ patients & $1(1,1)$ \\
\hline Alcohol & $71.5(60,79.8)$ \\
\hline Age & $2(1,5)$ \\
\hline ICU days & $10(6,19)$ \\
\hline Hospital days & $15(14,15)$ \\
\hline GCS & $1(0,2)$ \\
\hline VAS & $555(553,557)$ \\
\hline TISS & $24.5(19,27)$ \\
\hline NEECHAM & \\
\hline$n$ (\%) & $16(32 \%)$ \\
\hline MV & $18(36 \%)$ \\
\hline Smoking & $23(46 \%)$ \\
\hline Male & $23(46 \%)$ \\
\hline Opioids & $7(14 \%)$ \\
\hline Benzodiazepines & $19(38 \%)$ \\
\hline Antipsychotics & $23(46 \%)$ \\
\hline Operation & $40(80 \%)$ \\
\hline Planned admission & $11(22 \%)$ \\
\hline Restrictions & $11(28 \%)$ \\
\hline Death in ICU & $13(26 \%)$ \\
\hline Death in hospital & $16(32 \%)$ \\
\hline Delirium CAM & $5(10 \%)$ \\
\hline HYPER & $7(14 \%)$ \\
\hline HYPO & $4(8 \%)$ \\
\hline MIX & $14 \%)$ \\
\hline Delirium, NEECHAM & \\
\hline NEECHAM, mild & $12 \%)$ \\
\hline NEECHAM, risk & \\
\hline NEECHAM, normal & \\
\hline & \\
\hline
\end{tabular}

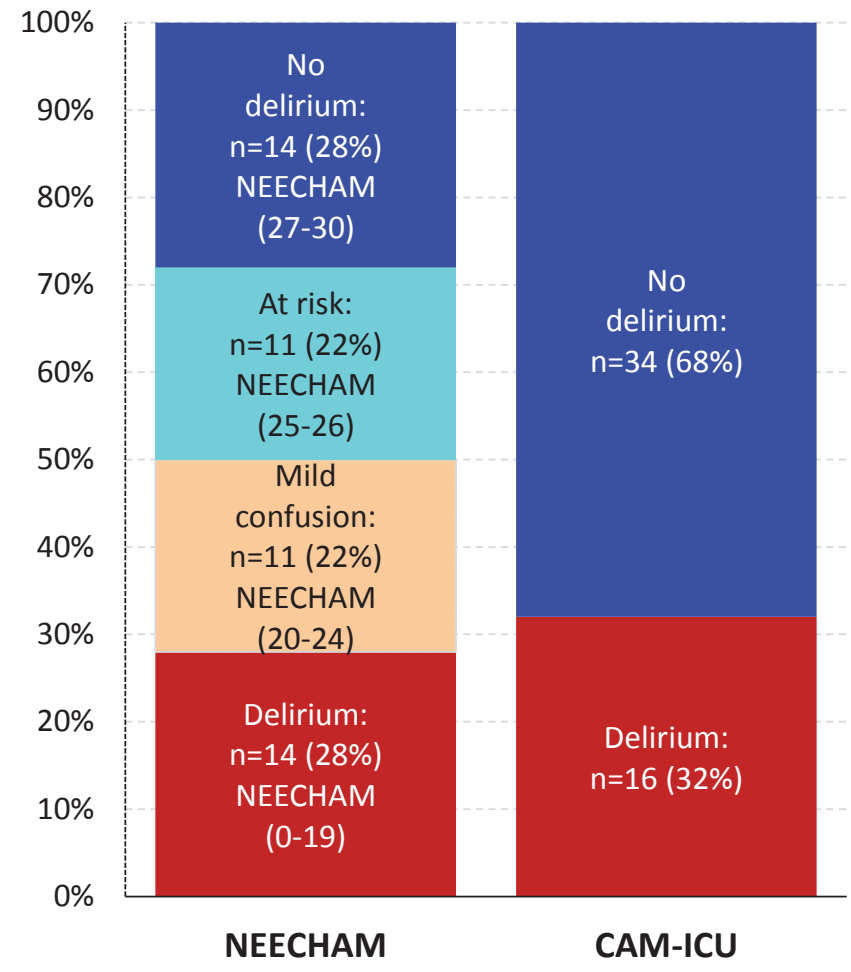

Fig. 2. Incidence of intensive care delirium assessed with Confusion Assessment Method for the Intensive Care Unit (CAM-ICU) and Neelon and Champagne (NEECHAM) Confusion Scale $(n=50$ patients)

Table 2. Distribution of the total population in a NEECHAM Confusion Scale versus CAM-ICU matrix

\begin{tabular}{lcccc} 
& \multicolumn{4}{c}{ NEECHAM Scale } \\
\cline { 2 - 5 }$n=50$ patients & Normal & Risk & Mild & Delirium \\
\hline CAM-ICU normal, $n=36$ & $14(100 \%)$ & $11(100 \%)$ & $8(72.7 \%)$ & $1(7.14 \%)$ \\
CAM-ICU delirious, $n=14$ & $0(0 \%)$ & $0(0 \%)$ & $3(27.3 \%)$ & $13(92.9 \%)$ \\
\hline
\end{tabular}

Table 3. Pearson's correlations and Cronbach's alpha for NEECHAM parameters $(n=389)$

\begin{tabular}{lccc} 
& Processing & Behavior & Physiologic control \\
\hline \multirow{2}{*}{ Processing } & 1.000000 & 0.723779 & 0.244455 \\
& 0.000000 & 0.000000 & 0.087099 \\
Behavior & 0.723779 & 1.000000 & 0.320739 \\
\multirow{2}{*}{ Physiologic control } & 0.000000 & 0.000000 & 0.023149 \\
\hline \multirow{2}{*}{ Cronbach's alpha $=0.703741}$. & 0.244455 & 0.320739 & 1.000000 \\
\hline
\end{tabular}


Table 4. Subgroup analysis for the incidence of delirium with CAM-ICU and NEECHAM Confusion Scale

\begin{tabular}{|c|c|c|c|c|c|c|}
\hline \multirow[b]{3}{*}{$n=50$ patients } & \multicolumn{2}{|c|}{ CAM-ICU } & \multirow[b]{3}{*}{$P$-value } & \multicolumn{2}{|c|}{ NEECHAM scale } & \multirow[b]{3}{*}{$P$-value } \\
\hline & Negative & Positive & & Negative & Positive & \\
\hline & \multicolumn{2}{|c|}{ Median (quartiles) } & & \multicolumn{2}{|c|}{ Median (quartiles) } & \\
\hline Alcohol & $1(1,1)$ & $1(1,1)$ & 0.304 & $1(1,1)$ & $1(1,1)$ & 0.672 \\
\hline Age & $71(60,79)$ & $72.5(60.8,83.3)$ & 0.942 & $70(59.8,79)$ & $73.5(66.5,83.8)$ & 0.347 \\
\hline ICU days & $1(1,3)$ & $5(1,9)$ & 0.055 & $1(1,3)$ & $6(2.25,9.75)$ & 0.004 \\
\hline Hospital days & $8(6,13.5)$ & $15.5(10.8,24.5)$ & 0.005 & $8(6,12.5)$ & $18(12.3,25.5)$ & 0.005 \\
\hline GCS & $15(15,15)$ & $14(13,14)$ & $<0.001$ & $15(15,15)$ & $14(13.3,14)$ & $<0.001$ \\
\hline VAS & $1(0,2)$ & $2(0,2.5)$ & 0.207 & $1(0,2)$ & $2(0.25,2.75)$ & 0.145 \\
\hline TISS & $557(555,557)$ & $553(553,557)$ & 0.035 & $557(555,557)$ & $553(553,557)$ & 0.036 \\
\hline NEECHAM & $26(24.3,27)$ & $16(13.5,19)$ & $<0.001$ & $26(24,27)$ & $15.5(12.5,16.8)$ & $<0.001$ \\
\hline \multicolumn{7}{|l|}{$n(\%)$} \\
\hline MV & $8(50 \%)$ & $8(50 \%)$ & 0.1028 & $9(56.3 \%)$ & $7(43.8 \%)$ & 0.105 \\
\hline Smoking & $11(61.1 \%)$ & $7(38.9 \%)$ & 0.5322 & $13(72.2 \%)$ & $5(27.8 \%)$ & 1 \\
\hline Male & $15(65.2 \%)$ & $8(34.8 \%)$ & 0.7666 & $16(69.6 \%)$ & 7 (30.4\%) & 0.761 \\
\hline Opioids & $16(69.6 \%)$ & $7(30.4 \%)$ & 1 & $17(73.9 \%)$ & $6(26.1 \%)$ & 1 \\
\hline Benzodiazepines & $5(71.4 \%)$ & $2(28.6 \%)$ & 1 & $5(71.4 \%)$ & $2(28.6 \%)$ & 1 \\
\hline Antipsychotics & $7(36.8 \%)$ & $12(63.2 \%)$ & $<0.001$ & $8(42.1 \%)$ & $11(57.9 \%)$ & 0.001 \\
\hline Operation & $14(60.9 \%)$ & $9(39.1 \%)$ & 0.373 & $15(65.2 \%)$ & $8(34.8 \%)$ & 0.361 \\
\hline Planned admission & $29(72.5 \%)$ & $11(27.5 \%)$ & 0.256 & $29(72.5 \%)$ & $11(27.5 \%)$ & 1 \\
\hline Restraints & $3(27.3 \%)$ & $8(72.7 \%)$ & 0.002 & $4(36.4 \%)$ & $7(63.6 \%)$ & 0.006 \\
\hline Death in ICU & $4(80 \%)$ & $1(20 \%)$ & 1 & $4(80 \%)$ & $1(20 \%)$ & 1 \\
\hline Death in hospital & $6(46.2 \%)$ & $7(53.8 \%)$ & 0.0824 & $7(53.8 \%)$ & $6(46.2 \%)$ & 0.149 \\
\hline Delirium CAM & $16(100 \%)$ & $0(0 \%)$ & $<0.001$ & $3(18.8 \%)$ & $13(81.3 \%)$ & $<0.001$ \\
\hline HYPER & $0(0 \%)$ & $5(100 \%)$ & 0.0021 & $1(20 \%)$ & $4(80 \%)$ & 0.018 \\
\hline HYPO & $0(0 \%)$ & $7(100 \%)$ & $<0.001$ & $2(28.6 \%)$ & $5(71.4 \%)$ & 0.014 \\
\hline MIX & $0(0 \%)$ & $4(100 \%)$ & 0.008 & $0(0 \%)$ & $4(100 \%)$ & 0.004 \\
\hline Delirium, NEECHAM & $1(7.14 \%)$ & $13(92.9 \%)$ & $<0.001$ & $0(0 \%)$ & $14(100 \%)$ & $<0.001$ \\
\hline NEECHAM, mild & $8(72.7 \%)$ & $3(25 \%)$ & 0.7331 & $11(100 \%)$ & $0(0 \%)$ & 0.022 \\
\hline NEECHAM, risk & $11(100 \%)$ & $0(0 \%)$ & 0.01 & 11 (100\%) & $0(0 \%)$ & 0.022 \\
\hline NEECHAM, normal & $14(100 \%)$ & $0(0 \%)$ & 0.002 & $14(100 \%)$ & $0(0 \%)$ & 0.005 \\
\hline
\end{tabular}

\section{Discussion}

The internal consistency of the NEECHAM Confusion Scale assessed with Cronbach's a was 0.703. In similar studies, it was calculated to be $\geq 0.81$ (Immers et al., 2005; Milisen et al., 2005; Poikajärvi et al., 2017). The lower value in our study may be explained by the sample size and structure. Thus, the NEECHAM Confusion Scale is reliable and may be used in non-intubated ICU patients (Matarese et al., 2013). The fact that, due to its current structure, the scale cannot be used in intubated individuals may considerably limit its routine application. The study results suggest that for assessing delirium in ICU patients, the physiological control items may not be relevant as they scored lowest. Our findings are consistent with those in a Dutch study by Immers et al. (2005), which stated that the physiological control items could be removed. Reducing the scale from nine to six items would make it more user-friendly; however, more studies would be needed to confirm this. The present study found that the incidence rates detected by the CAM-ICU (32\%) and NEECHAM Confusion Scale (28\%) were comparable. Interestingly, nearly a third of CAM-ICU-negative patients $(n=22)$ were found to be mildly confused $(n=11)$ or at risk for confusion $(n=11)$ with the NEECHAM Confusion Scale. More detailed classification such as this may be important for timely preventive measures (Ashtarian et al., 2019). Also, a Japanise study by Matsushita et al. (2004) indicated that the NEECHAM Confusion Scale (categorical approach) should be useful for the detection of postoperative delirium in the surgical ward. A Belgian study by Van Rompaey et al. (2008) showed similar results for the incidence of delirium assessed CAM-ICU and the NEECHAM scale $19.8 \%$ and $20.3 \%$ respectively and stated, that scale were comparable. The time consuming nature of assessment tools is reported as the most important barrier to routine delirium assessment. Other barriers are the lack of prioritization of results, 
lack of education of the staff, or the work environment (Rowley-Conwy, 2018). While the mean time for completing the NEECHAM Confusion Scale is $3.6 \pm 1.2$ minutes, assessment with the CAM-ICU takes approximately 2-3 minutes (Devlin et al., 2007). This suggests the latter may be perceived as a more user-friendly tool (Poikajärvi et al., 2017). Even though only two variables (a GCS score and use of antipsychotics) were found to be statistically significant $(p<0.001)$, some other parameters studied in delirium-positive patients were on the borderline of statistical significance $(p=0.002-0.055)$. Those were the hospital stay, ICU stay, TISS score and use of physical restraints. Albeit non-significant, these data indirectly confirm results from previous studies (Guillory et al., 2021) ICU delirium is a predictor of increased mortality, prolonged hospitalisation and mechanical ventilation, increased treatment costs, as well as increased risks of reintubation and of transferring the affected patient to a longterm health care facility (hospital-acquired complications).

\section{Recommendations}

- A suitable assessment tool may help nurses recognize delirium in patients.

- The CAM-ICU and NEECHAM Confusion Scale showed comparable incidence rates of delirium in the ICU.

- There are many barriers to routine delirium assessment in the ICU.

\section{Study limitations and recommendations}

One limitation of the study is the single-center design. Another is the small sample size. For valid and comprehensive evaluation of the phenomenon, a high-quality multi-center randomized study should be performed.

\section{Conclusions}

Several tools for delirium diagnosis are used in clinical practice. Routine monitoring for delirium is part of the status assessment of ICU patients. The study found that the incidence rates detected by the CAM-ICU (32\%) and NEECHAM Confusion Scale (28\%) were comparable. Additionally, it showed that thanks to its classification, the NEECHAM Confusion Scale may identify patients at risk for delirium earlier. The NEECHAM Confusion Scale is a reliable delirium assessment tool, but the fact that it cannot be used in intubated patients considerably limits its wider use in the ICU (as compared with the CAM-ICU).

\section{Acknowledgements}

We would like to thank the nurses from AGEL Hospital in Valašské Meziřičí hospital for helping with data collection, Martin Hill for statistical analysis, and Pavel Kurfürst for translating the text.

\section{Ethical aspects and conflict of interests}

The authors declare that there is no conflict of interest regarding the study and that ethical aspects were considered while processing the results. All literature sources were properly cited.

\section{Funding}

The study was supported by AGEL internal grant, project no.: INT 2019003.

\section{Author contributions}

Concept and design (HL), data collection (HL, JP), analysis and interpretation of the data (HL), processing and design of the manuscript (HL), supervision and manuscript revision (JP).

\section{Srovnání hodnocení deliria pomocí Confusion Assessment Method for the Intensive Care Unit a Neelon and Champagne Confusion Scale a u neintubovaných pacientů na jednotce intenzivní péče}

\section{Souhrn}

Úvod: Existuje mnoho škál hodnocení a predikce rizika deliria, ale jsou málo známé a nejsou rutinně používané zdravotníky v praxi. Diagnostika deliria sestrami je nadále omezená řadou limitací.

Design: Prospektivní observační studie zahrnovala 50 konsekutivních neintubovaných pacientů, kteří byli hospitalizováni na JIP déle než 24 hodin.

Místo: Anesteziologicko-resuscitační oddělení (5 lůžek) Nemocnice AGEL ve Valašském Meziříčí, od září 2020 do března 2021. Metody: Primárním výstupem bylo porovnání přítomnosti deliria u neintubovaných pacientů na JIP se dvěma současně užívanými hodnoticími nástroji: Neelon and Champagne (NEECHAM) Confusion Scale (škála zmatenosti) a Confusion Assessment Method for the Intensive Care Unit (CAM-ICU). Sekundárním výstupem bylo ověření spolehlivosti NEECHAM Confusion Scale v prostředí české jednotky intenzivní péče.

Výsledky: Studie zjistila, že incidence deliria pomocí CAM-ICU (32 \%) a NEECHAM Confusion Scale (28 \%) byly srovnatelné. Současně bylo zjištěno, že téměř třetina CAM-ICU negativních pacientů patří do skupiny mírné zmatenosti nebo hodnocena jako riziková u NEECHAM Confusion Scale. Vnitřní konzistence NEECHAM Confusion Scale, hodnocená pomocí Cronbachovy a, byla 0,703. Statisticky významný vztah byl potvrzen mezi deliriem a dvěma ze sledovaných parametrů pacienta (skóre GCS a užívání antipsychotik).

Závěr: Delirium je běžné u pacientů na intenzivních péčích, ale často zůstává nediagnostikováno. K identifikaci byly vyvinuty různé nástroje, které pomáhají detekovat pacienty s deliriem a jejich použití vede k lepším výsledkům. Oba studované nástroje (CAM-ICU a NEECHAM Confusion Scale) se zdají být vhodné a uživatelsky pohodlné.

Klíčová slova: akutní ošetřovatelství, CAM-ICU, delirium, jednotka intenzivní péče, NEECHAM Confusion Scale (škála zmatenosti), neintubovaní pacienti 


\section{References}

1. Ashtarian H, Mehrabi N, Bazrafshan MR, Rahmati M (2019). Validation of the NEECHAM confusion scale for intensive care delirium assessment. J Health Sci Surveill Sys 7(4): 178-182. DOI: 10.30476/JHSSS.2020.85687.1073.

2. Balková M, Tomagová M (2018). Use of measurement tools for screening of postoperative delirium in nursing practice. Cent Eur J Nurs Midw 9(3): 897-904. DOI: 10.15452/ CEJNM.2018.09.0021.

3. Černá Pařízková R (2019). Delirium v intenzivní péči. Vnitr Lek 65(6): 433-439. DOI: 10.36290/vnl.2019.077.

4. Cherak SJ, Soo A, Brown KN, Ely EW, Stelfox HT, Fiest KM (2020). Development and validation of delirium prediction model for critically ill adults parameterized to ICU admission acuity. PloS One 15(8): e0237639. DOI: 10.1371/journal. pone.0237639.

5. Cribbin D (2018). Review: Communication with invasive mechanically ventilated patients and the use of alternative devices: integrative review. J Res Nurs 23(7): 631-632. DOI: $10.1177 / 1744987118786142$.

6. Devlin JW, Fong JJ, Fraser GL, Riker RR (2007). Delirium assessment in the critically ill. Intensive Care Med 33(6): 929-940. DOI: 10.1007/s00134-007-0603-5.

7. Devlin JW, Skrobik Y, Gélinas C, Needham DM, Slooter A, Pandharipande PP, et al. (2018). Clinical practice guidelines for the prevention and management of pain, agitation/sedation, delirium, immobility, and sleep disruption in adult patients in the ICU. Crit Care Med 46(9): e825-e873. DOI: 10.1097/ CCM.0000000000003299.

8. Dušek L, Pavlík T, Jarkovský J, Koptíková J (2011). Analýza dat v neurologii XXIX. - Spolehlivost (reliabilita) klinických testů. Cesk Slov Neurol N 74/107(5): 594-599.

9. Grover S, Kate N (2012). Assessment scales for delirium: a review. World J Psychiatry 2(4):58-70. DOI: 10.5498/wjp. v2.i4.58.

10. Guillory J, Fitz-Gerald C, Banik A, Sterwald C, Ashiofu E, Knox E, et al. (2021). Comparison of hospital course and outcome in hospital-acquired vs pre-existing delirium. Ann Clin Psychiatry 33(1): 35-44. DOI: 10.12788/acp.0021.

11. Gusmao-Flores D, Salluh JIF, Chalhub RÁ, Quarantini LC (2012). The confusion assessment method for the intensive care unit (CAM-ICU) and intensive care delirium screening checklist (ICDSC) for the diagnosis of delirium: a systematic review and meta-analysis of clinical studies. Crit Care 16(4): R115. DOI: $10.1186 / \mathrm{cc} 11407$.

12. Helgesen AK, Adan YH, Dybvik Bjørglund C, Weberg-Haugen C, Johannessen M, Åsmul Kristiansen K et al. (2021). Nurses' experiences of delirium and how to identify delirium a qualitative study. Nurs Open 8: 844-849. DOI: 10.1002/ nop2.691.

13. Ho MH, Montgomery A, Traynor V, Chang CC, Kuo KN, Chang HR, et al. (2020). Diagnostic performance of delirium assessment tools in critically ill patients: A systematic review and meta-Analysis. Worldviews Evid Based Nurs 17(4): 301-310. DOI: 10.1111/wvn.12462.

14. Immers HE, Schuurmans MJ, van de Bijl JJ (2005). Recognition of delirium in ICU patients: a diagnostic study of the
NEECHAM confusion scale in ICU patients. BMC Nurs 4(1): 7. DOI: 10.1186/1472-6955-4-7.

15. Káňová M, Burda M, Povová J, Neiser J (2015). Delirium u kriticky nemocných - prospektivní studie. Cesk Slov Neurol N 78(6): 662-667.

16. Matarese M, Generoso S, Ivziku D, Pedone C, De Marinis MG (2013). Delirium in older patients: a diagnostic study of NEECHAM Confusion Scale in surgical intensive care unit. J Clin Nurs 22(19-20): 2849-2857. DOI: 10.1111/j.13652702.2012.04300.x.

17. Matsushita T, Matsushima E, Maruyama M (2004). Early detection of postoperative delirium and confusion in a surgical ward using the NEECHAM confusion scale. Gen Hosp Psychiatry 26(2): 158-163. DOI: 10.1016/j.genhosppsych.2003.08.011.

18. Milisen K, Foreman MD, Hendrickx A, Godderis J, Abraham IL, Broos PL, et al. (2005). Psychometric properties of the Flemish translation of the NEECHAM Confusion Scale. BMC Psychiatry 5: 16. DOI: 10.1186/1471-244X-5-16.

19. Mitášová $A$, Bednařík $J$, Koštálová $M$, Michalčáková $R$, Ježková M, Kašpárek T, et al. (2010). Standardizace české verze The Confusion Assessment Method for the Intensive Care Unit (CAM-ICUcz). Cesk Slov Neur N 73/106 (3): 258-266.

20. Neelon VJ, Champagne MT, Carlson JR, Funk SG (1996). The NEECHAM Confusion Scale: construction, validation, and clinical testing. Nurs Res 45(6): 324-330. DOI: 10.1097/00006199-199611000-00002.

21. Poikajärvi S, Salanterä S, Katajisto J, Junttila K (2017). Validation of Finnish Neecham Confusion Scale and Nursing Delirium Screening Scale using Confusion Assessment Method algorithm as a comparison scale. BMC Nursing 16: 7. DOI: 10.1186/s12912-016-0199-6.

22. Pun BT, Ely EW (2007). The importance of diagnosing and managing ICU delirium. Chest 132(2): 624-636. DOI: 10.1378/ chest.06-1795.

23. Rowley-Conwy G (2018). Barriers to delirium assessment in the intensive care unit: A literature review. Intensive Crit Care Nurs 44: 99-104. DOI: 10.1016/j.iccn.2017.09.001.

24. Serafim RB, Soares M, Bozza FA, Lapa E Silva JR, Dal-Pizzol F, Paulino MC, et al. (2017). Outcomes of subsyndromal delirium in ICU: a systematic review and meta-analysis. Crit Care 21(1): 179. DOI: $10.1186 / \mathrm{s} 13054-017-1765-3$.

25. Van Rompaey B, Schuurmans MJ, Shortridge-Baggett LM, Truijen S, Elseviers M, Bossaert L (2008). A comparison of the CAM-ICU and the NEECHAM Confusion Scale in intensive care delirium assessment: an observational study in non-intubated patients. Crit Care 12(1): R16. DOI: 10.1186/cc6790.

26. Waterfield D, Barnason S (2021). Use of PADIS assessment tools by critical care nurses: An integrative review. West J Nurs Res 43(9): 843-858. DOI: 10.1177/0193945920973025.

27. Wild D, Grove A, Martin M, Eremenco S, McElroy S, VerjeeLorenz A, et al. (2005). Principles of good practice for the translation and cultural adaptation process for patient-reported outcomes (PRO) measures: report of the ISPOR task force for translation and cultural adaptation. Value Health 8(2): 94-104. DOI: 10.1111/j.1524-4733.2005.04054.x.

28. Zhang Z, Pan L, Ni H. (2013). Impact of delirium on clinical outcome in critically ill patients: a meta-analysis. Gen Hosp Psychiatry 35(2): 105-111. DOI: 10.1016/j. genhosppsych.2012.11.003. 